\title{
Pelatihan perencanaan optimalisasi sistem lahan pertanian masyarakat Desa Kramat Kabupaten Lamongan
}

\author{
Rio Rahma Dhana ${ }^{1 *}$, Armanda Lutfi Febrianto ${ }^{2}$ \\ 2Teknik Sipil, Fakultas Teknik,Universitas Islam Lamongan, Lamongan \\ riorahma@unisla.ac.id
}

\begin{abstract}
Reservoir is a container or place for storing raw water, which will later be used as a temporary water storage area, then used as a place for water treatment for the continued growth of rice plants. In addition to rice plants, reservoirs are also used to minimize drought disasters in the dry season. The construction of this reservoir will be used by the Kramat village community to improve the economy in two sectors, namely agriculture and village potential, Kramat village itself is one of the villages in Lamongan Regency which has an area of 194.80 hectares and is located in Lamongan sub-district which has a population of 2,012 people. Most of their livelihoods are farmers. Seeing such conditions, farmers need facilities to help meet the needs of raw water for their agricultural land which will be planned with the planning method carried out by the construction of the reservoir with various stages such as measuring with 2 methods, either surveying in the field or utilizing digital applications or software using fields area or Google earth, after finding the size, then we can determine the sketch of the image on the reservoir by drawing in AutoCAD software. The area of land used for the construction of the reservoir has an area of 1,452.03 $\mathrm{m} 2$, which is later estimated to be able to accommodate $8,507,190 \mathrm{~L}$ of water. The total volume of excavation work is $8,507.19 \mathrm{~m} 3 \mathrm{with}$ an estimated work period of 23 days. Excavator pc 200 heavy equipment operational cost : Rp. 101.200.000 per 23 days and for Dump truck capacity of 8 m3: Rp. 2,400,000 (2 dump trucks) per day.
\end{abstract}

Keywords: reservoir; drought; heavy equipment; analysis

\begin{abstract}
Abstrak
Embung merupakan wadah atau tempat penyimpanan air baku, yang nantinya digunakan sebagai tempat penyimpanan air sementara, kemudian digunakan sebagai tempat pengolahan air untuk kelangsungan pertumbuhan tanaman padi. Selain untuk tanaman padi embung juga digunakan untuk meminimalisir bencana kekeringan pada musim kemarau. Pembangunan embung ini nantinya digunakan masyarakat desa kramat untuk meningkatkan perekonomian di dua sektor yaitu pertanian dan potensi desa, desa kramat sendiri merupakan salah satu desa di kabupaten lamongan yang mempunyai luas 194,80 hektar dan terletak di kecamatan lamongan yang mempunyai populasi penduduk sebanyak 2.012 jiwa yang sebagian besar mata pencahariannya menjadi petani. melihat kondisi seperti itu sehingga dibutuhkan sarana pembantu petani untuk mencukupi kebutuhan air baku untuk lahan pertaniannya yang akan direncanakan dengan Metode perencanaan yang dilakukan pembangunan embung dengan berbagai tahapan seperti pengukuran dengan 2 metode baik survei di lapangan atau memanfaatkan aplikasi digital atau software menggunakan fields area ataupun google earth, setelah ditemukan ukuran barulah kita bisa menentukan sketsa gambar pada embung dengan menggambar di software autocad. Luas lahan yang digunakan untuk pembangunan embung mempunyai luas 1.452,03 $\mathrm{m} 2$, yang nantinya diperkirakan dapat menampung air sebanyak 8.507.190 L. Jumlah volume pekerjaan galian tanah adalah 8.507,19 m3 dengan estimasi pekerjaan selama 23 hari. Biaya operasional alat berat Excavator pc 200 : Rp. 101.200 .000 per 23 hari dan untuk Dump truck kapasitas 8 m3 : Rp. 2.400 .000 ( 2 dump truck) per hari.
\end{abstract}

Kata Kunci: embung; kekeringan; alat berat; analisa 


\section{PENDAHULUAN}

Air merupakan kebutuhan terpenting untuk kelangsungan hidup bagi semua makhluk hidup terutama manusia. Meskipun perannya begitu penting, namun untuk pengelolaannya sendiri masih jauh apa yang diharapkan, maka dari itu dibutuhkan adanya fasilitas atau prasarana untuk tempat pengolahan air itu sendiri, seperti pembangunan embung (Heryani et al., 2020). Embung merupakan wadah atau tempat penyimpanan air baku, yang nantinya digunakan sebagai tempat penyimpanan air sementara pembangunan embung ini dilakukan tepatnya di desa Kramat kecamatan lamongan, tujuan dari pembangunan embung ini untuk mengelola air, untuk meminimalisir adanya bencana kekeringan pada musim kemarau, terkhusus untuk lahan pertanian di desa Kramat. Setelah dilakukannya musyawarah dengan pihak pemerintah desa perlu kiranya memanfaatkan APBDES yang nantinya akan diusulkan pada Musdes dan akan dilanjutkan ke pemerintahan daerah atau dinas terkait agar segera terealisasi.

Mendengarkan usulan dari masyarakat desa dan kelompok tani pada bulan kemarau kondisi lahan pertanian setelah panen padi pada periode ke 2 banyak lahan yang tidak gunakan, melihat kondisi seperti itu masyarakat desa tidak melakukan kegiatan bercocok tanaman padi, alternatifnya masyarakat di desa melakukan dengan kegiatan penanaman palawija yang tidak banyak membutuhkan banyak air, selain menjadi aktivitas sehari hari bagi para petani tanaman palawija juga bisa meningkatkan ekonomi di sektor pertanian. Disisi lain embung juga dimanfaatkan sebagai sarana pemancingan umum yang nantinya akan dikelola karang taruna atau bumdes, jika nantinya perencanaan sukses maka desa kramat dapat meningkatkan perekonomian di dua sektor pertanian dan potensi desa. Luas lahan yang digunakan untuk pembangunan embung mempunyai luas $\pm 1.452,03 \mathrm{~m}^{2}$, yang nantinya diperkirakan dapat menampung air sebanyak 8.507.190 L.

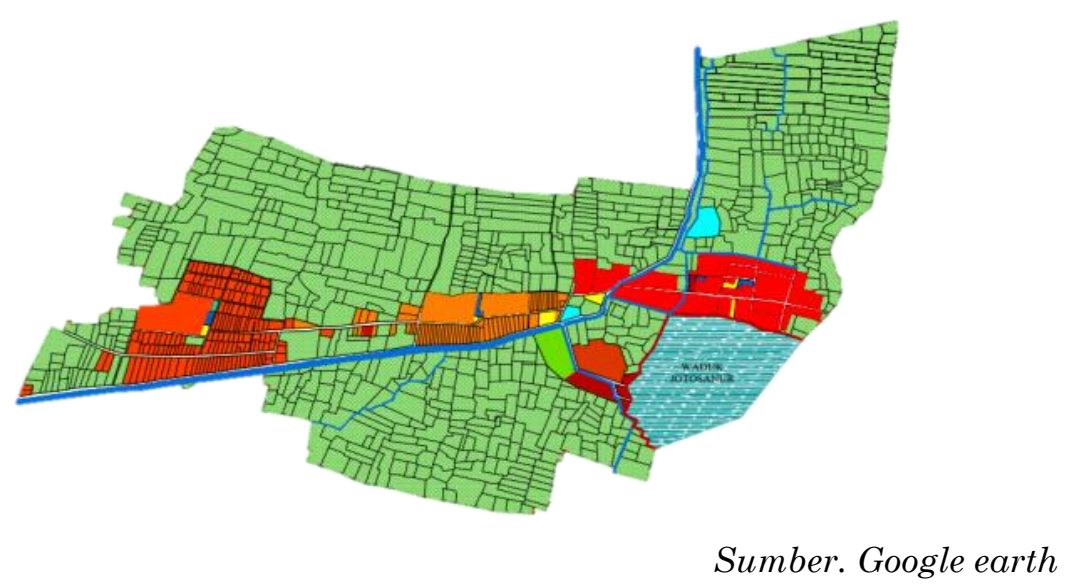

Gambar 1. Peta Desa Kramat

Desa Kramat merupakan salah satu dari 12 desa di wilayah Kecamatan Lamongan, yang terletak ke arah selatan berbatasan dengan Kecamatan Tikung, Desa Kramat 
mempunyai luas wilayah seluas 194,80 hektar. Adapun batas-batas wilayah desa Kramat:

a. Sebelah utara : Berbatasan dengan Desa Wajik Kecamatan Lamongan.

b. Sebelah selatan : Berbatasan dengan Desa Guminingrejo Kec. Tikung.

c. Sebelah timur : Berbatasan dengan Desa Jotosanur Kec. Tikung.

d. Sebelah barat : Berbatasan dengan Desa Rancangkencono Kec. Lamongan.

Iklim Desa Kramat, sebagaimana desa - desa lain di wilayah Indonesia mempunyai iklim kemarau dan penghujan, hal tersebut mempunyai pengaruh langsung terhadap pola tanam yang ada di Desa Kramat Kecamatan Lamongan.

Desa Kramat terdiri dari 3 dusun diantaranya Dusun Cekel; Dusun Ngablak dan Dusun Kramat; dengan jumlah penduduk 2.012 Jiwa atau 547 KK. Mata pencaharian penduduk di Desa Kramat sebagian besar masih berada di sektor pertanian. Hal ini menunjukkan bahwa sektor pertanian memegang peranan penting dalam bidang ekonomi masyarakat, maka dari itu kebutuhan air sangat diperlukan mengingat tanaman padi memerlukan air, untuk bertumbuh dengan baik. Sehingga diperlukan prasarana tempat tampungan air yang memadai. Pada musim kemarau tiba terjadi kekurangan air pada lahan pertanian di desa kramat dikarenakan pengelolaannya yang kurang maksimal, maka dari itu dibutuhkan prasarana yang nantinya dapat mengelola air dengan baik pada musim kemarau yakni dengan pembuatan embung. Adapun tujuan penelitian ini adalah untuk mengetahui besaran air yang dapat ditampung pada embung. Untuk manfaat dari penelitian adalah dengan adanya prasarana yang memadai untuk pengelolaan air yang nantinya digunakan sebagai air cadangan untuk tanaman pada desa kramat.

\section{METODE PELAKSANAAN}

Dalam penelitian ini metode yang digunakan adalah metode pemetaan. Metode pemetaan melewati beberapa proses yaitu pengukuran, perhitungan, dan penggambaran permukaan bumi yang dapat di jelaskan sebagai berikut :

\section{Pengukuran}

Pengukuran dilakukan dengan 2 metode, manual dan google earth, pengukuran manual dilakukan dengan cara survey ke tempat, sedangkan dengan google earth digunakan sebagai alat bantu virtual dan memuhdahkan dalam pengukuran, pengukuran dilakukan dengan melibatkan pihak - pihak yang bersangkutan (Syaripudin, 2014).

\section{Perencanaan gambar}

Perencanaan gambar dilakukan dengan cara mengumpulkan data dari pengukuran, perencanaan gambar juga tidak bisa sembarangan dikerjakan, harus dengan orang yang faham atau mengetahui tentang dunia perencanaan, perencanaan gambar ini 
akan menghasilkan shop drawing yang nantinya dijadikan dalam pelaksanaan proyek konstruksi. Dari metode pelaksanaan perencanaan gambar dengan bantuan software autocad dapat langsung menghitung luas area dan volume, sehingga dapat diketahui berapa liter air yang dapat di tamping (Hatta, Purnomo, and Maulana, 2012).

\section{Galian Dan Timbunan}

Penggalian tanah dilaksanakan dengan cara menggunakan alat berat excavator dan tanah dari galian diangkut menggunakan dump truck, sebelum melakukan penggalian hal - hal sebagai berikut perlu diperhatikan seperti :

a) Cek kondisi lahan

b) Melihat gambar proyek

c) Memasang batas galian

d) Menganalisis pelaksanaan pekerjaan

Untuk pekerjaan galian hanya dilakukan dengan orang ahli atau orang yang sudah bersertifikat dalam mengendalikan alat berat (Febrianti, Zakia, and Mawardi, 2021).

\section{HASIL DAN PEMBAHASAN}

Pekerjaan perencanaan embung desa dilakukan dengan beberapa tahap :

\subsection{Pengukuran Lokasi (google earth)}

Merupakan sebuah ilmu, seni dan teknologi untuk menentuan posisi relatif, suatu titik di atas, atau di bawah permukaan bumi. Dalam arti yang lebih umum, survey (geomatik) dapat didefenisikan; sebuah disiplin ilmu yang meliputi semua metode untuk mengukur dan mengumpulkan informasi tentang fisik bumi dan lingkungan, pengolahan informasi, dan menyebarluaskan berbagai produk yang dihasilkan untuk berbagai kebutuhan. Metode pengukuran pertama dilakukan dengan memanfaatkan teknologi virtual yaitu program google earth, yang bisa menunjukan permukaan muka bumi dengan cara mencari lokasi yang nantinya dijadikan embung desa (Harahap and Kristian, 2017).

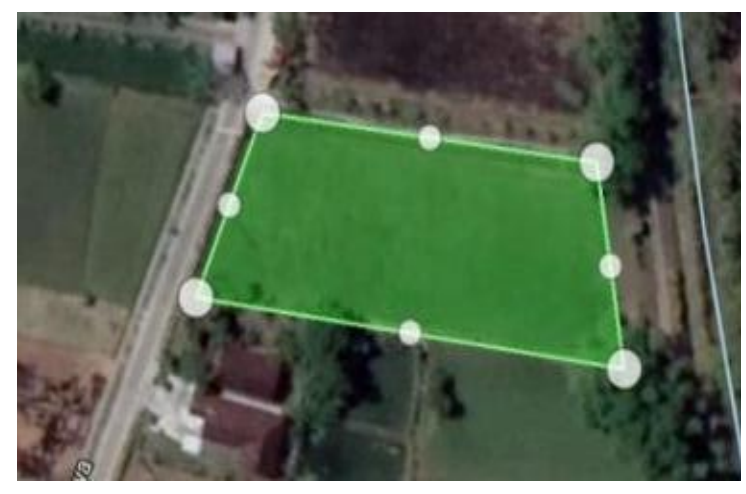

Sumber. Google earth

Gambar 2. Layout Peta Desa Kramat 


\subsection{Peninjauan lokasi}

Dalam melaksanakan tugas diatas, surveyor harus mempertimbangkan aspek hukum, ekonomi, lingkungan, dan sosial yang relevan sehingga proyek tetap berjalan secara normal. Pekerjaan mengukur tanah dan pemetaan (Survei dan pemetaan) meliputi pengambilan/ pemindahan datadata dari lapangan ke peta atau sebaliknya. Pengukuran yang akan dipelajari dibagi bagi dalam pengukuran mendatar dari titik titik yang terletak diatas permukaaan bumi, dan pengukuran tegak guna mendapatkan beda tinggi antara titik-titik yang diukur diatas permukaan bumi yang tidak beraturan (Nabilah, Pratiwi, and Vidyana, 2020) yang pada akhirnya dapat digambar diatas bidang datar (Peta). Ilmu ukur tanah merupakan ilmu sebagai dasar dalam melaksanakan pekerjaan survey atau ukur mengukur tanah.Dalam bidang teknik sipil, meliputi pekerjaan-pekerjaan untuk semua proyek pembangunan, seperti perencanaan dan pembuatan gedung, jembatan, jalan, saluran irigasi. Sedangkan dalam bidang pertanian untuk perncanaan proyek seperti : pembukaan lahan baru, saluran irigasi dll.(Syaifullah, Wahyono, and Susmiyanto, 2019).

Peninjauan lokasi ini dilakukan untuk melihat keadaan sesungguhnya yang nantinya akan disesuaikan dengan google earth.

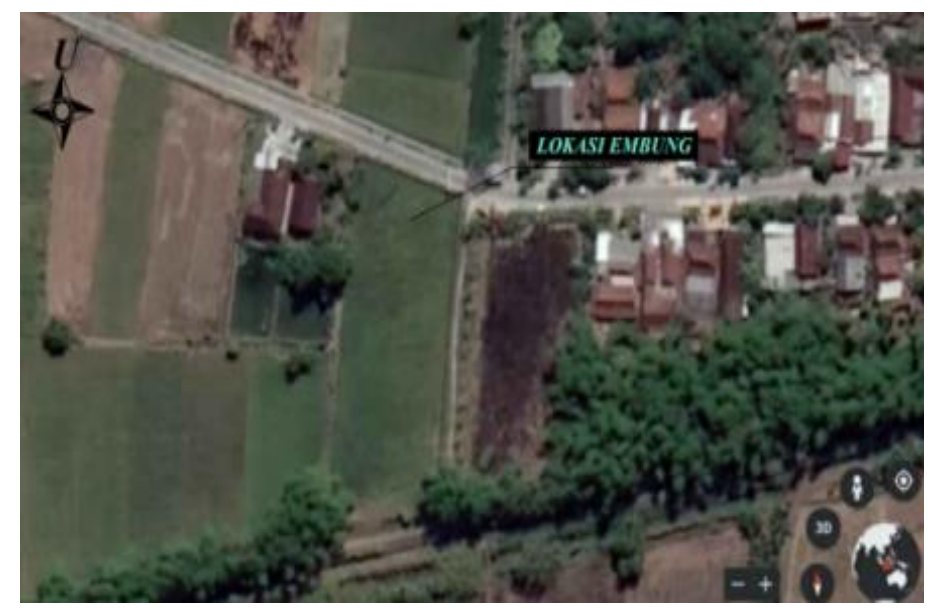

Sumber. Google Earth

Gambar 3. Layout Peta Desa Kramat

\subsection{Pengukuran lokasi (manual)}

Penentuan ukuran dan bentuk bumi, pengukuran dari semua data yang diperlukan untuk menentukan ukuran, posisi, bentuk, dan kontur pada setiap bagian bumi dan memantau setiap perubahan.

1. Penentuan posisi objek/titik pada sebuah ruang dan waktu serta posisi dan pemantauan bentuk fisik, struktur dan pekerjaan yang berada di atas atau di bawah permukaan bumi

2. Pengembangan, pengujian dan kalibrasi sensor, peralatan dan sistem untuk pekerjaan Survei 
3. Perolehan dan penggunaan informasi tata ruang dari jarak dekat, udara dan citra satelit dan proses-proses yang dapat dilakukan secara otomatis.

4. Penentuan dari posisi batas-batas tanah masyarakat atau pribadi, termasuk batasbatas nasional dan internasional, dan pendaftaran lahan tersebut dengan pihak yang berwenang

5. Perencanaan dan pembentukan system informasi geografis (GIS) suatu daerah dan mengumpulkan, menyimpan, menganalisis, mengelola, menampilkan dan menyebarkan data (Syaripudin, 2014).

Pengukuran lokasi dilakukan dengan dua tahap, untuk pertama dengan bantuan google earth, dan yang kedua pengukuran langsung kelapangan atau lokasi dengan melibatkan perangkat desa. Setelah melakukan pengukuran ditemukan dengan total luas lahan $1.452,03 \mathrm{~m}^{2}$.

\subsection{Perencanaan gambar embung}

Perencanaan gambar dilakukan dengan menggunakan software AutoCAD, proses pekerjaan ada beberapa gambar yang harus dikerjakan.

\section{a. Sketsa lokasi}

Gambar sketsa lokasi memperlihatkan kondisi sekitar yang akan dilakukan pekerjaan proyek embung.

b. Gambar rencana embung

Gambar rencana ini dilihat dari tampak atas yang menunjukan bagian dari rencana pembuatan embung.

c. Potongan embung

Gambar potongan adalah gambar yang digunakan untuk menegetahui detail seluruh bagian bangunan embung (Haryati, 2018).

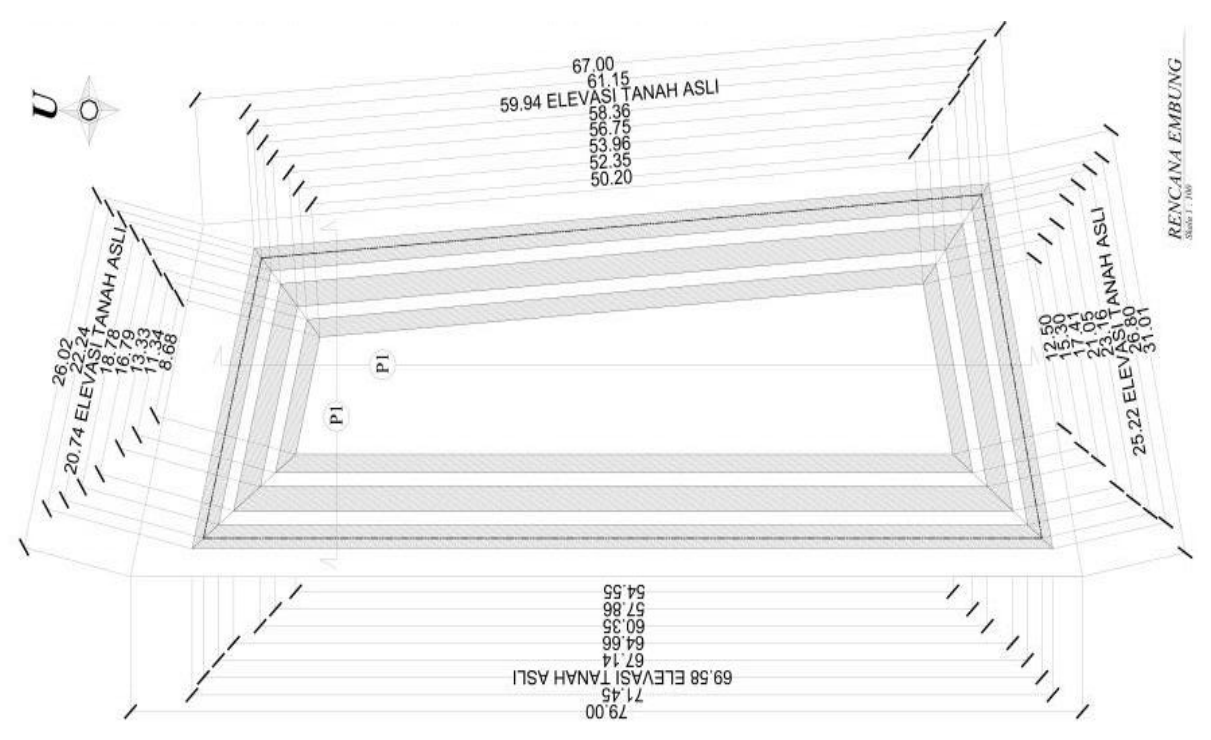

Gambar 4. Gambar Rencana

Sumber. Peneliti 
Dari proses perencanaan gambar dapat langsung menghitung luas tanah yang akan digunakan sebagai embung dan kapasitas air pada embung.

\subsection{Analisa galian dan timbunan}

Pada analisa galian yang dilakukan ialah menghitung produktivitas alat berat (excavator pc 200) dan biaya operasional, berikut tahap - tahap dalam perhitungan produktivitas alat berat.(Suhendra, Dwiretnani, and Endika, 2019)

a. Pekerjaan galian

Untuk menghitung produktivitas excavator pada pekerjaan galian digunakan rumus sebagai berikut:

$$
Q=\frac{\sum x K \times 3600}{W}
$$

\section{Dengan :}

Kapasitas bucket $(\Sigma): 1 \mathrm{~m}^{3}$

Efisiensi kerja (K) : 0,8 (baik)

Waktu (W) : $60 \operatorname{detik} / \mathrm{m}^{3}$

$$
\begin{aligned}
\text { Produktivitas }(Q)=\frac{1 \times 0.8 \times 3600}{60} \\
\mathrm{Q}=48 \mathrm{~m}^{3} / \mathrm{jam}
\end{aligned}
$$

Jadi produktivitas excavator pada pekerjaan galian sebesar $48 \mathrm{~m}^{3 / \mathrm{jam}}$ (Oetomo and Rudiansyah 2014).

b. Volume galian

Volume galian sudah terhitung dengan menggunakan bantuan autocad, diperoleht volume pekerjaan galian sebesar 8.507,19 $\mathrm{m}^{3}$. Untuk gambar galian bisa melihat pada gambar detail potongan (Supit, 2020).

c. Waktu pengerjaan

Untuk mengetahui waktu yang dibutuhkan dalam pekerjaan galian ini dapat dihitung menggunakan rumus :

$$
\mathrm{W}=\mathrm{V} / \mathrm{Q}
$$

Dengan :

$\mathrm{V}=$ volume galian $8.507,19 \mathrm{~m}^{3}$

$\mathrm{Q}=$ produktivitas excavator $48 \mathrm{~m}^{3} / \mathrm{jam}$

Maka waktu yang diperlukan adalah :

$\mathrm{W}=8.507,19 \mathrm{~m}^{3} / 48 \mathrm{~m}^{3} / \mathrm{jam}=177,2 \mathrm{jam}$

Excavator beroperasi dalam sehari 8 jam, maka waktu yang dibutuhkan adalah 
$\mathrm{W}=177,2 \mathrm{jam} / 8 \mathrm{jam} / \mathrm{hari}=22,15=23$ hari

Jadi waktu yang diperlukan untuk pekerjaan galian membutuhkan 23 hari.(Purwaamijaya, 2008)

d. Menghitung biaya excavator pc 200

Untuk biaya sewa excavator per jam sebesar Rp. 550.000 itu sudah termasuk biaya bahan bakar, mobilisasi, upah operator, dan lain-lain, jadi untuk perhitungan biaya per-hari untuk galian adalah Rp. $550.000 \times 8$ jam/hari $=$ Rp. 4.400.000.

Dalam proses penggalian membutuhkan waktu 23 hari, maka didapat biaya sebesar Rp. 4.400.000 x 23 hari = Rp. 101.200.000. untuk total keseluruhan biaya yang diperlukan untuk persewaan excavator adalah seratus satu juta dua ratus ribu rupiah.(Yadam, Diputra, and Sudipta, 2018)
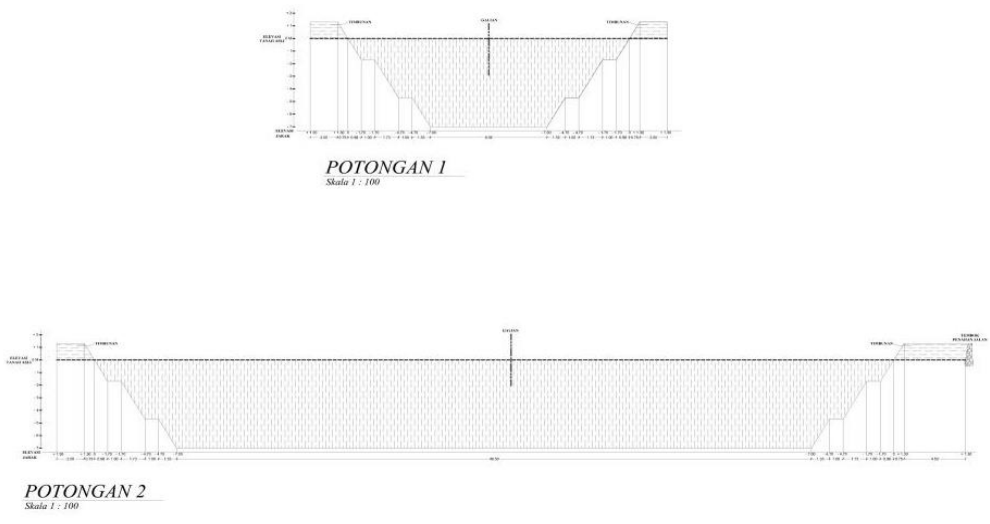

Sumber. Peneliti

Gambar. 5 Rencana Potongan

\subsection{Biaya operasional dump truck}

Dump truck digunakan sebagai alat pengangkut material dari galian, untuk itu dump truck memiliki peran penting dalam proyek pembangunan embung. Sebelum menghitung biaya operasional dump truck perlu kiranya untuk menghitung kebutuhan dump truck terlebih dahulu, berikut tahap-tahap yang dikerjakan :

a. Data yang diperoleh dari dump truck

Kapasitas dump truck $\quad: 8 \mathrm{~m}^{3}$

Jarak pengangkutan : $1 \mathrm{~km}$

Kecepatan isi $\quad: 20 \mathrm{~km} / \mathrm{jam}$

Kecepatan kosong $\quad: 30 \mathrm{~km} / \mathrm{jam}$

Waktu isi

$: 1 / 20 \times 60=3$ menit

Waktu kosong $\quad: 1 / 30 \times 60=2$ menit 
Waktu loading $\quad: 4$ menit

Waktu maneuver, dumping : 2 menit

Jadi total waktu yang ditempuh adalah 11 menit

b. Kebutuhan dump truck

waktu sirklus excavator $x$ kapasitas dump truck

$\frac{60 \frac{\mathrm{sec}}{\mathrm{m}^{3}} \times 8 \mathrm{~m}^{3}}{60}=8$ menit

Dump truck untuk 1 excavator $=\frac{11 \text { menit }}{8 \text { menit }}=1,3$

Dibulatkan menjadi 2 dump truck (Febrianti and Zakia, 2019)

c. Biaya sewa Dump truck

Untuk biaya sewa dump truck per jam sebesar Rp. 150.000 itu sudah termasuk biaya bahan bakar, mobilisasi, upah operator, dan lain-lain, jadi untuk perhitungan biaya per-hari untuk dump truck adalah Rp. 150.000 × 8 $\mathrm{jam} / \mathrm{hari}=$ Rp. 1.200.000. Dan ada 2 dump truck yang bekerja, jadi upah sewa yang dikeluarkan adalah Rp. 2.400.000 per hari.

\section{SIMPULAN}

Adapun kesimpulan yang dapat diambil adalah pekerjaan perancangan embung dilakukan dengan tahap pengukuran, perancangan desain, dan pekerjan galian. Pada proses pengukuran ada 2 metode yang dapat digunakan, yaitu dengan metode Google earth dan manual. Pembuatan desain embung menggunakan software auto $C A D$, dan menghasilkan gambar kerja berupa : sketsa, gambar rencana, dan potongan. Dari pengukuran lahan yang digunakan untuk pembangunan embung mempunyai luas $1.452,03 \mathrm{~m}^{2}$, yang nantinya diperkirakan dapat menampung air sebanyak $8.507 .190 \mathrm{~L}$. Jumlah volume pekerjaan galian tanah adalah $8.507,19 \mathrm{~m}^{3}$ dengan estimasi pekerjaan selama 23 hari. Biaya operasional yang di keluarkan untuk penyewaan alat berat Excavator pc 200 adalah Rp. 101.200 .000 per 23 hari dan untuk kendaraan Dump truck kapasitas $8 \mathrm{~m}^{3}$ menghabiskan biaya penyewaan Rp. 2.400 .000 (2 dump truck) per hari.

\section{UCAPAN TERIMA KASIH}

Penulis menyampaikan terimakasih kepada semua pihak yang telah membantu dalam pelaksanaan kegiatan Program Pengabdian Masyarakat ini. Secara khusus penulis ingin mengucapkan terimakasih dan penghargaan yang setinggitingginya kepada Rektor Universitas Islam Lamongan dan Dekan fakultas teknik universitas islam lamongan dan tak lupa dengan masyarakat desa yang selalu membantu memberikan dukungan serta kesediaan kepada penulis untuk dapat melaksanakan kegiatan program pengabdian masyarakat ini. 


\section{REFERENSI}

Febrianti, D., \& Zakia, Z.. (2019). Analisis Durasi dan Perhitungan Biaya Penyusutan (Depresiasi) Alat Berat Excavator. Jurnal Teknik Sipil.

Febrianti, D., Zakia Z.,, \& Edi, M. (2021). Analisis Biaya Operasional Alat Berat Pada Pekerjaan Timbunan. Tameh: Journal of Civil Engineering.

Harahap, L. H., \& Kristian. (2017). Kontribusi Penggunaan Peralatan Ukur Tanah Terhadap Hasil Belajar Survey dan Pemetaan Siswa Kelas XI Program Keahlian Teknik Konstruksi Batu dan Beton SMK Negeri 2 Binjai. Jurnal Pendidikan Teknologi Dan Kejuruan.

Haryati, S. R. (2018). Kajian Desain Embung di Tepian Kota Yang Mengarah Pada Pengembangan Ekowisata Berbasis Ekonomi Kreatif. Jurnal Arsitektur Dan Perencanaan (JUARA).

Hatta, F., Adhi ,P., \& Arris, M. (2012). Perancangan Media Pembelajaran Autocad Berbasis Teknologi Informasi dan Komunikasi (TIK) Pada Mata Pelajaran Produktif Teknik Gambar Bangunan dalam Bentuk Cakram Optik. Jurnal PenSil.

Heryani, N., Budi, K., Adang, H., \& Budi, R. (2020). Analisis Ketersediaan dan Kebutuhan Air Irigasi Pada Lahan Sawah: Studi Kasus di Provinsi Sulawesi Selatan. Jurnal Tanah Dan Iklim.

Krisnayanti, Denik, S., Elsy E. H., Tri M. W. Sir, E. N. M., \& Alvine. C., Damayanti. (2020). Perencanaan Embung Wae Lerong untuk Pemenuhan Kebutuhan Air Irigasi di Daerah Irigasi Wae Lerong Ruteng Provinsi NTT. Jurnal Irigasi.

Nabilah, R., Rian, A. P., \& Cipta, V. (2020). Analisis Pesepsi dan Preferensi di Embung A Sebagai Komponen Pengelolaan Embung di Institut Teknologi Sumatera. Jurnal Lanskap Indonesia.

Oetomo, W., \& Rudiansyah. (2014). Perencanaan Penggunaan Alat Berat dan Biaya (Studi Kasus Kegiatan Pembangunan Sekolah Terpadu Samarinda). Fakultas Teknik, Jurnal Untag, Sipil.

Purwaamijaya, I. M. (2008). Teknik Survei dan Pemetaan Jilid 1.

Suhendra, S., Annissa, D., \& Endika, E. (2019). Optimasi Alat Berat Pada Pemindahan Tanah Mekanis (Studi Kasus Penyediaan Timbunan Tanah Pilihan Pada Pekerjaan Peningkatan Akses Jaringan Pipa Air Bersih Kabupaten Tanjung Jabung Barat, Booster Senyerang). Jurnal Talenta Sipil.

Supit, D. D. (2020). Analisa Produktivitas dan Efisensi Alat Berat untuk Pekerjaan Tanah, dan Pekerjaan Perkerasan Berbutir. Journal Dynamic Saint.

Syaifullah, A., Eko, B. W., \& Agus, S. (2019). Modul Ilmu Ukur Tanah. Kementrian Agraria dan Tata Ruang / Badan Pertanahan Nasional.

Syaripudin, A. (2014). Pengantar Survey dan Pengukuran. Pengantar Survey dan Pengukuran.

Yadam, R. W., I. G. A. D.,\& I. G. K. S. (2018). Optimalisasi Penggunaan Alat Berat Pada Pekerjaan Galian Tanah. Jurnal Ilmiah Elektronik Infrastruktur Teknik Sipil OPTIMALISASI. 